\title{
CONTROL OF CONTENTS OF THE BROADCASTS IN TURKISH LAW
}

\author{
Sevil Yildiz \\ Assoc. Prof. Dr., Selcuk University, Communication Faculty, TURKEY \\ syildiz@selcuk.edu.tr
}

\begin{abstract}
Media, which has big effect at the formation of the culture at the societies having democratic management system, is qualified as the fourth power after legislation, executive and jurisdiction. Audiovisual media, when their functions are taken into account in addition to their political effects, is accepted as the most effective tool of the mass media. For the audiovisual media, wide spreading and becoming an integral part of society life in process of time, to perform its functions in a healthy way, the regulation and control of this field have become a state of important necessity.

In Turkish Law Radio and Television Supreme Council, performing the control of audiovisual media, is an independent administrative authority. RTSC has become a constitutional institution with the inclusion of an additional paragraph inserted into article 133 of the Constitution by means of the Law no 5370 . Authorized by the Law no 6112 on the Establishment and Broadcasting of Radio and Television Companies to release the broadcasting companies, to inspect the organizations and to impose sanctions in cases of violation of the provisions, the decisions of RTSC are subject to judicial review.

The control of the contents of broadcasts by the Council is examined in this study. In the control of broadcasts, the direct control, audience based and self control- joint control practices have been considered. Recommendations upon the control systems being applied in Turkey have been made. Also with selfregulation and co-regulation practices, general trend towards more effective and successful applications of the control mechanism through the shared responsibility between supervisory authorities and the independent broadcasters has also determined.
\end{abstract}

Keywords: Radio and Television Supreme Council, broadcast contents, self-control, joint control

\section{INTRODUCTION}

As a result of the rapid developments occurred at mass media in 1990s, due to the arise of the necessity of being subject to European Convention on Transfrontier Television, Convention was signed by Turkey on September 7, 1992. Pursuant to the Convention, the monopoly of the state at audio-visual media was removed in year 1993 by the amendment made in Article 133 of 1982 Constitution, legal infrastructure of private broadcasting was formed. Afterwards entrance to broadcasting sector was liberalised and the number of private television institutions increased rapidly (Kejanlıoğlu, 2004, 84). 
Following the Constitution amendment, the sub regulations with respect to broadcasting were implemented. Within the direction of the mentioned constitution amendment, Law upon Establishment and Broadcasts of Radio and Television No. 3984, dated 13.04.1994 including the regulations upon private radio and television broadcasts (Abolished) entered into force. Thus, instead of Radio and Television High Council, Radio and Television Supreme Council (RTSC) of which the powers and responsibilities are determined in a broader manner, independent, impartial and holding the nature of public legal entity, assigned with the regulation and control of radio and television services, is established. Pursuant to Law upon Establishment and Broadcasts of Radio and Television No. 3984, RTSC is assigned with the regulation and control of the radio and television broadcasting field at national, regional and local level. It is entrusted with the powers such as frequency planning, granting license and broadcasting permission, bringing regulations upon broadcasts, controlling the compliance of the broadcasts with these regulations and imposing sanctions to the institutions, broadcasting in contradiction with these.

RTSC's duties and powers, provided in Law No.6112 can be divided into two as those related with regulation and those with the controlling (Öztekin, 2007, 32). Duties and powers such as frequency planning, causing frequency planned, applying frequency, allocating channel and frequency, determining standard, preliminary condition and fees regarding broadcast permission and license, performing studies and incentives upon common -control and self control can be expressed as several of those related with the regulation. The controlling activities performed by RTSC can be classified as; control of broadcast contents, technicalstructural control upon ownership structure and technical standards of broadcaster institutions and the financial control upon the transfer of commercial communication revenues of broadcaster institutions. Monitoring and controlling of broadcasting services, imposing the necessary sanctions in case of contradiction with the legislation can be enumerated within the duty and powers with respect to content control (Gürsoy, 2011, 18). As of the subject of the study, merely the broadcast content control will be discussed below.

\section{THE BROADCAST CONTENT CONTROL}

RTSC, pursuant to paragraph (e) and (f) of Article 37 of the Law No. 6112, controls the broadcasting services of media service providers as regards the compliance with the provisions at Law and international agreements to which they are party and cooperates with the concerned international organisation and institutions, when required. The controlling activities carried out by RTSC stand on three fundamental bases. These can be named as direct control, audience control and self-control. Direct control is the control means where broadcasts are monitored by RTSC specialists without being subject to any application or complaint and considering regulations such as related laws, regulations. Audience control is however performed by the evaluation of audience complaints, arriving from 4441178 RTSC Communication Centre, RTSC web page and RTSC e mail channels, by the specialists. Self- control is the control conducted by broadcasters in person by broadcasting ethical principles and practices such as institution of audience representation (RTSC Web Page, 2011).

With the Law Upon Establishment and Broadcast Services of Radio and Television No. 6112, RTSC's establishment, organisation, procedures and principles regarding duty, power and responsibilities are regulated again by taking acquit Communitarian into account. In Article 37 of Law No. 6112, it is possible to enumerate the other provisions upon broadcast contents, being distinguished out of the duties and powers of RTSC enumerated according to Supreme Council's characteristic of being an authority, regulating and controlling broadcasting service sector, as follows:

- Ensuring the freedom of expression and intelligence, thought diversity, competition environment and pluralism within the field of broadcasting services, provided that the duty and powers of Competition Authority are reserved, prevention of concentration and taking the necessary precautions for the protection of public interest.

- Installation of the monitoring and recording systems required for the monitoring and control of broadcasting services, to the studios of broadcaster institutions when necessary.

- Determination of the procedure and principles regarding the protective symbol system to be given place at broadcasting service by media service providers.

- Following up the developments regarding broadcasting services, determination of general strategies upon sector, mechanisms of joint control, self-control and joint regulation; performing studies and incentives enabling the development of broadcasting services in our country; organisation of training and certificate programmes for employees of media service providers and furnishing certificate.

- Cooperation with the other public organisations, particularly Ministry of National Education, in order to 
popularise media literacy in a manner including all parts of the society (Kızıl, 1998, 66).

The principles, which are required to be complied with by media service providers within the broadcasting activities, forming the fundamental framework of the monitoring and supervision activities carried out by RTSC, stated in Article 8 of $3^{\text {rd }}$ section with the heading of Broadcast Service Principles, of the Law No. 6112 are as follows:

"Media service providers provide broadcasting services, in compliance with the principles in this paragraph and with the understanding of public responsibility. Broadcast services cannot;

- contradict with the existence and independency of State of Turkish Republic, the indivisible integrity of the country and nation of State, principles and reforms of Atatürk,

-provoke the society to hatred and hostility or form hatred feelings at the society by making discrimination as regards race, language, religion, gender, class, region or sect,

- contradict of rule of law, principle of justice and impartiality,

- contradict with the honour of people or confidentiality of private life; include insulting, humiliating expressions beyond the limits of criticising person or institutions or those in the nature of slander,

- praise or encourage terrorism, demonstrate the terrorist organisations as powerful or right, reflect the threatening and deterrent characteristics of terrorist organisations, present the terrorist act, its offenders and victims in a manner serving for the purposes of terror ,

- include or encourage broadcasts society by making discrimination or humiliating individuals due to reasons such as race, colour, language, religion, nationality, gender, disability, political and philosophic thought, sect and similar reasons,

- contradict with national and spiritual values of the society, general morals and principle of protection of family,

- be in the nature of praising commitment of offense, offender or criminal organisation, instructing crime techniques.

- include abuses against children, weak and disabled people or encourage the violence,

- in the nature of inspiring the use of alcohol, tobacco products and addictive drugs or gambling,

- must take the principles of impartiality, reality and truth into account and not prevent the formation of free opinion at the society; the news of which investigation is allowed under professional principles of press cannot be published without being investigated or ensured upon the accuracy thereof; in presentation of the news no exaggerated voice or image, effect or music other than the natural sound are allowed; it is a must to specify that images are the source of the news obtained from agencies or another media source through achieve or impersonation,

- Unless the fact that someone is guilty becomes final with an award, nobody can be announced as guilty or shown as guilty; cannot hold a nature affecting the jurisdiction process or impartiality, other than those in the nature of news, throughout the jurisdiction process upon the issues under jurisdiction,

- include elements serving for unjust interest or causing unfair competition,

- be in the nature of unilateral or partial with respect to political parties and democratic groups,

- encourage the acts that may cause harm to general health, protection of environment and animals,

- must provide the right, beautiful and understandable use of Turkish with its features and without departing from the rules; no low quality, rude or slang use of language are not allowed,

- be obscene,

- must respect to the answer and correction right of the person or institutions,

- include contest or lottery through information communication means, give or cause to give bounty to listeners of audiences,

- The survey and poll made or caused to made by media service provider must be performed before notary from their preparation stage to the announcement of its results,

- Abuse persons by means of fortune telling or superstitious beliefs, 
- include programmers contradicting with social gender equality, encourage pressures upon women or abuse women,

- promote or inure violence.

Radio and television broadcasting services cannot broadcast programmes including contents that may cause harm to the physical, mental or moral development of children and young people at the time zone they may watch or without using protective symbols (Avşar\&Demir, 2005, 180).

Voluntary broadcasting service providers are obliged to broadcast programmes that may negatively affect the physical, mental or moral development of children and young people in a manner where this kind of services cannot be heard or seen by these under the normal conditions."

In determination of these provisions, setting the framework of those to which the broadcasting service content is subjected, the principles upon freedom of thought and intelligence of Constitution, European Convention on Human Rights, European Convention on Transfrontier Television and European Union Directive of Audio- Visual Media Services have been taken into account.

By inserting special provisions for radio and television broadcasting services and voluntary broadcasting services, children and young audiences are aimed to be protected. With the provisions at the new article, the ambiguities and gaps at Law No. 3984 have been removed. Briefly, by protecting through the article the freedom of content of the broadcaster, the provisions for considering the fundamental standard of judgment of the society and particularly for the protection of children and young people have taken place.

Furthermore, following the broadcasting service principles set forth in Law No. 6112, there are principles and provisions upon commercial communication, advertisement and teleshopping, commercial communication of certain products, product placement having an important place at the control. Regulation upon Procedure and Principles of Broadcasting Service, including more detailed provisions for the implementation of these principles, entered into force on 02.11.2011.

\subsection{Direct Control}

Media service providers are under the obligation of presenting the broadcasting services in compliance with these principles with the understanding of public responsibility. The control of the compliance of the broadcasts with broadcasting service principles is under the responsibility of RTSC experts. With direct control activities, it is determined by the experts whether the broadcasting service principles are violated or not, reports upon the violating broadcasts are issued. The specialist reports regarding breach of broadcasting principles are considered and evaluated at the weekly meetings, regularly held by Supreme Council (Özenirler, 2006).

Due to the fact that broadcasting recording systems used for the monitoring of broadcasts fall beyond technology within time and frequent failures thereof, in order to remove these problems by developing a new system, Digital Record Achieve and Analysis System (SKAAS) Project was prepared by TÜBITAK. This system, put into practice in year 2008, enables the recording, archiving, easily monitoring and controlling of the radio and television broadcasts within the bounds of daily technological possibilities at the digital environment. Owing to the system, the radio and television broadcasts can be recorded, monitored and analysed for $7 / 24$. The specialist assigned at Supreme Council's Monitoring and Evaluation Department can monitor the broadcasts in a more efficient manner and make several analyses thereupon owing to the renovations and conveniences brought by SKAAS. System enables expert to issued their report in a short time and in an efficient manner and submit to Supreme Council. SKAAS, at where the broadcasts of national channels within the last 1 year and those of other channels within the last 6 months are kept, enables the easy access to the broadcast at the required date and the rapid screening of the broadcast content by the method of "key squares" (Palzer \& Scheuer, 2003, 117).

Until recently the monitoring and control of the broadcasts made in provinces and districts have been performed by the monitoring units at General Directorate of Security, pursuant to the protocol signed in year 1998 between General Directorate of Security and RTSC and revised in year 2006. The broadcasting violations determined by these units have been submitted by reports to RTSC and evaluated by the experts assigned at Monitoring and Evaluation Department. In order to monitor and control the local and regional broadcasts from sole centre, Province /District SKAAS Project has been put into practice. Thus the monitoring and control of the broadcasts can be performed by the centre in Ankara. With the completion of the project of transportation of local broadcasts to the centre, approximately 200 local and regional television broadcasts can be digitally recorded, monitored and analyzed. Owing to the system, enabling the transfer of broadcasts in electronically environment, the local and regional television broadcasts can be evaluated and 
controlled by the experts in a more efficient manner.

\subsection{Audience Based Control}

Audience based control is where the control is performed by the direct communication of the opinion, recommendation and complaints upon radio and television broadcasts by audiences and listeners through 4441178 RTSC Communication Centre, webpage with the extension of www.rtuk.org.tr and e-mail. The arriving complaints are directed to the experts, responsible for the daily monitoring of broadcasting institutions at computer environment, in order to be evaluated as soon as possible. In addition thereto the complaints are regularly communicated to the audience representatives of broadcast institutions. The notices arriving from audiences are statistically evaluated and reported to Supreme Council. Furthermore the analysed notices are also forwarded to the audience representatives of television channels.

4441178 RTSC Communication Centre is established with the duty entrusted by the Law to Radio and Television Supreme Council to constantly monitor and evaluate the reaction, like and sensibility, formed with respect to the broadcasts. RTSC gives great importance to the opinions of listeners and audiences, giving rise to their active contribution to the control process. By RTSC Communication Centre, making announcements at the radio and televisions with the slogan of "We are waiting for your calls, we care about your opinion", audiences and listeners are encouraged to express their opinion. Therefore the cost of calling the Communication Centre from every broadcast of the country, accessible at every hour of the day is priced as domestic call fee.

\subsection{Self-Control and Joint -Control Practices}

The duty of "determination of joint-control, self-control and joint regulation mechanisms" provided under the Law No. 6112 is enumerated among the duties of RTSC. At the end of the cooperation and joint studies performed with the broadcasting institutions in order for the self-control to be more functional and have a broader implementation field, the practices named "Audience Representation" and "Broadcasting Ethical Principles" have been put into practice.

The audience representation practice is a project announced to public on September 29, 2006 at the end of the studies jointly carried out with the Television Broadcasters' Association and put into practice on December 8, 2006. The project aiming the broadcasters' forming their self-control mechanisms and developing them, has been put into practice with the cooperation of national television channels, without any obligation or legal sanction. The audience representation has gained a legal basis by being regulated with Law upon Establishment and Broadcast Services of Radio and Television No. 6112, entered into force on March, 2011. By virtue of the importance given to self- control, it is aimed with the practice to enable television audiences to find addressees when they want to access to television channels to inform complaints upon the broadcasts they are watching. Owing to this system, audience can directly communicate with the television channels in order to express opinion or make complaint with respect to the programs. By this means, opinion, complaints and reactions of audiences can be regularly followed by channel managers and officers and the broadcasts can be revised or prepared for broadcasting by taking this point of views into account. Thus, a direct interaction is provided between audience and television channels. Audiences can see whether their opinions are taken into account or not by television channels. And, the audience opinions forwarded to RTSC through 4441178 RTSC Communication Center are regularly transferred to "Audience Representatives" of television channels.

In order for the sound functioning of the control mechanism of audience representation, sound feedbacks from the audiences are required. In order to ensure this, the projects such as "Smart Signs" and "Media Literacy" with respect to increasing the consciousness of audience in our country, have been put into practice.

The concept of media ethics is an important concept as regards the self-control within broadcasting activities. The concept of ethics expresses a common conscious, generally related with every part of the society, deliberatively endeavoring to find the "good" one and ensure the "good" one in every field. Within this respect it is possible to say that the concept of media ethics fundamentally reflects the deliberate concordance between the common likes and values of the society with the mass media. At this point, in year 2007 Ethical Principles of Broadcasting were determined with the cooperation of the academicians having important studies in the field of media ethics and Turkish Television Broadcasters' Association (TVYD). Afterwards, opinions of Professional Union of Radio Television Broadcasters (RATEM) and Union of Local and Regional Televisions (YBTB) and of the broadcasters, member of TVYD, upon text have been received and conciliation has been provided. The Ethical Principles of Broadcasting, composed of 12 articles, being specified under the common opinion of persons, representing the different sections of the society, was 
undertaken by being signed on July 3, 2007 by all of the parties, including broadcaster institutions. These principles, reflecting the common conscience of the society, a good example of self-control and joint control practices are enumerated as follows:

- Respect to honour, fundamental right and liberties of people,

- Accurate, impartial and complete broadcasting of the incident and facts under the freedom of expression and intelligence,

- Not abusing broadcasting within the direction of unjust purpose and interests,

- Giving importance to the protection of pluralism and cultural diversity,

- Not having race, colour, language, religion and gender discrimination, humiliation and prejudices at broadcasts,

- Respect to the right of respond and correction of person and institutions,

- Acting prudent against the events that may create fear and indignation in society and in crisis times,

- Taking care not to encourage or legitimate the violence,

- Respect to private life and confidentiality,

- Being sensitive to the problems of women and refraining from objectifying women,

- Showing attention to protect children and young people from inappropriate content,

- Giving importance to the needs, like and sensibilities of audience and listeners.

After the common decision taken at the meeting of "Media Sensibility", organised by RTSC in year 2010, to which Ministry of Internal Affairs, Undersecretaries of Public Order and Security, General Directorate of Security, Members of Turkish Television Broadcasters' Association and the leading broadcasters of our country participated, "Principles to be Complied with in Journalism in Terror and Extraordinary Cases" were determined under the cooperation of TVYD and broadcaster institutions. This mentioned study is an important joint- control study performed for the provision of self-control. If media does not show the necessary sensibility, it may unintentionally become a propaganda means of the terror. When it is taken into account that the main purpose of terror is making propaganda, by organizing acts causing fear and panic in the society, to what extent the journalism is sensitive, can be understand better. Therefore the compliance with the mentioned journalism principles has vital importance.

\section{CONCLUSION}

With the regulation and control activities at audio-visual media, it is aimed to ensure the common interest, closely related with every section of the society. Different control mechanisms have arisen due to the practices carried out in order to achieve this target within time. These mechanisms are generally enumerated as state supervision, self-control, joint control and public supervision. Since each control type has its own features, their advantage and disadvantages differ.

The state supervision expressing the traditional regulation system at audio-visual media is the system where broadcasting principles are determined by regulatory organization or institutions and regulation and supervision activities are performed according to these criteria. It can be said that the self-control mechanism applied for the provision of editorial independence and freedom of expression of the broadcasters does not have the adequate efficiency or functionality in our country. It is observed that the broadcasting institutions, putting commercial concerns to forefront do not duly perform self-control activities. In order for the sound operability of self-control, ethical principles of broadcasting must be internalized by media professionals and the broadcasts must be performed accordingly (Thompson, 2008, 91).

The model applied in order to find new solutions to the failing aspect of self-control mechanism can be named as joint-control. In the joint -control model, completion of the failing administrative binding and sanction aspects of self-control mechanism is aimed. Joint-control is for the realization of a more efficient control at a common point, which is the public interest, by bringing the controlling section and the one being controlled together. Joint- control needs new practices and projects, regarding the coordination between broadcasters and administrative mechanisms. Another control model is the control model where the effects such as public pressure, arisen within the direction of opinions of audience/user to which the broadcasters address, are the main leading element. Public pressure and reactions arriving from audience/users have a great effect upon broadcaster institutions. Generally being not watched/ listened means the decrease of 
ratings, which is the biggest profitable element, for the broadcasters, broadcasting with commercial concerns. Therefore being not watched/ listened create a big sanction effect for the broadcasters. The model enabling the inclusion of audience /users into control system can be seen as an example for participatory democracy practice. Conscious audience/user may provide a more efficient and successful control. Therefore, practices and projects that may create conscious to audience/users should be put forward. The supervision role undertaken by broadcasting institutions and public opinion essentially has a determinative role upon the fundamental function of the control mechanism. The institutions, providing broadcasting service, are generally in the opinion of being away from the supervision of state, rather than being at the center thereof. However when the supervision methods being recently applied in the world and its consequences are taken into account, it is seen that at the models having more active function within the supervision structure of the state, supervision activities bear more efficient conclusions. The efficient auto control mechanisms that can be applied by the internal audit systems of broadcasting institutions and the public supervision that may have beneficial consequences are supported by several states. In a broadcasting sector having broadcasting institutions able to control itself together with active and conscious audience/user mass and related control mechanisms, state supervision will not be needed. When the subjective element of supervision, hardening the supervision, is taken into consideration, in order to reach this ideal state it is important for audience- mass, NGOs, media institutions and all of the society sections to work in efficient manner within communion and consistent communication environment. Therefore, the required attempts to increase the number and efficiency of the audience associations and self-control institutions, of which the lack is felt to a large extent in our country, that may perform an efficient public supervision, should be made.

It is seen that the broadcasting service principles regulating radio and television broadcasting in Turkey have regulations including state supervision, self-control, joint-control, public supervision mechanisms and provisions of contracting international agreements in broadcasting. When the historical process regarding self -control is examined, it is seen that regulations upon audiovisual media have not been adequately considered. Therefore, in Turkey where merely state control has taken place throughout the structural development process of the sector, it has become an important need to take the burden of the control upon this structure away from self-control and joint- control practices. In order to ensure the functionality of self control and joint-control practices, through meeting several parts of the society at a common ground, the studies carried out under the leadership of RTSC should be seen as the important developments in this field.

Under the light of all of this information, the performance of broadcasting services by the broadcaster institutions within total communication freedom must not be perceived as eliminating the rules and principles required to be complied by these institutions within the scope of social responsibility understanding. On the other hand, it is important for the regulations made by the state to refrain from the pressure and elements that may make the broadcasting field, to be applicable and understandable. In order to establish the best balance at all of the regulations and practices, including the control at audiovisual media, it is important for all of the parties to act with a common conscience and awareness of their responsibilities.

\section{REFERENCE LIST}

Avşar, Z \& Demir, V. (2005), Düzenleme ve Uygulamalarla Medyada Denetim, Piramit Yayıncılık, Ankara.

Gürsoy, Y.(2011), 6112 sayılı Radyo ve Televizyonların Kuruluş ve Yayın Hizmetleri Hakkında Kanun Getirdiği Değişiklikler ve Yenilikler, Scala Yayıncılık, İstanbul.

Kejanlıoğlu, B. (2004), Türkiye'de Medyanın Dönüşümü, İmge Kitapevi, Ankara.

Kızıl, N. E. (1998), İletişim Özgürlüğü ve Medyada Oto-kontrol, Beta Yayınları, İstanbul.

Özenirler, I. (2006), Kitle İletişimde Denetim, Denetim Modelleri ve Özellikle Radyo-Televizyon Yayıncılığında Denetim, Gazi Üniversitesi, Ankara.

Öztekin, H. (2007), Radyo ve Televizyon Alanının Düzenlenmesi ve Denetlenmesinde Yeni Eğilimler ve Yönelimler, Erciyes Üniversitesi Sosyal Bilimler Enstitüsü, Yayımlanmamış Yüksek Lisans Tezi, Kayseri.

Palzer, C. \& Scheuer, A. (2003), "Self-Regulation, Co- Regulation, Public Regulation", Florence, http://www.emrsb. de/news/Palzer_Scheuer_Unseco-Clearinghouse_Yearbook2004.pdf, (05.06.2010) 
RTÜK Web Sayfası, Görsel-İşitsel Medya Hizmetleri Yönergesi,

http://www.rtuk.gov.tr/sayfalar/IcerikGoster.aspx?icerik_id=e49885dc-005b-4ccca381-7789260607b5, (05.01.2011)

Thompson, John B. (2008), Medya ve Modernite, (Çev. Serdar Öztürk), Kırmızı Yayınları, İstanbul. 